\title{
Uudelleentulkitut Augustinuksen diakonit
}

Bart J. Koet

The Go-Between. Augustine on Deacons. Leiden: Brill. 2019. $169 \mathrm{~s}$.

Heti alkuun on tunnustettava, ettei tämä arvostelu ole, eikä tehtävän mahdottomuuden vuoksi yritäkään olla, täysin puolueeton. Tilburgin yliopiston eksegetiikan professori Bart J. Koet toimi vastaväittäjänäni ja olemme muutoinkin tehneet yhteistyötä diakonian tutkimukseen liittyvien projektiemme parissa viime vuosina. Kun siis luin hänen tuoretta kirjaansa, en voinut olla kuvittelematta kirjoittajan lempeää puheääntä tekstin takana. Kirja myös pohjautuu osittain Koetin What did deacons do? -kongresseissa pidettyihin esityksiin, joita olin seuraamassa. Vaikka en allekirjoita kaikkia Koetin painotuksia, voin lämpöisesti suositella kirjaa sekä kirkkoisä Augustinuksesta että yleisesti varhaiskirkon ajan diakoniasta kiinnostuneille lukijoille.

Koet on jakanut tutkimuksensa kahdeksaan lukuun. Kolme ensimmäistä käsittelevät uudelleenmääriteltyä diakoni-käsitettä. John N. Collinsia seuraten Koet luo ensin katsauksen Uuden testamentin aikana kirjoitettujen kristillisten ja ei-kristillisten tekstien tapaan käyttää diakonos-käsitettä. Hän myös pohtii diakoneja ja diakonian virkaa varhaisessa kirkossa. Erityisesti kaksisäikeisen viran kehitystä on tarkasteltu huolellisesti. Lukujen tavoite on taustoittaa seuraavien lukujen analyysiä. Määritellyt käsitteet ja kysymyksenasettelut tulevat uudelleen vastaan, kun Koet käsittelee Augustinuksen tekstejä. Ensimmäisissä luvuissa luotu katsaus ja käsitteenmärittelyt ovat kuitenkin hyödyllisiä myös lukijoille, jotka ovat kiinnostuneita yleisesti varhaiskirkon diakoniasta.

Neljännessä luvussa Koet siirtyy Augustinukseen. Kirkkoisän henkilöhistoria ja Augustinus-tutkimuksen näkökulmat tulevat tarkastelluiksi ensin, mikä luo uskottavan ja ymmärrettävän pohjan myöhemmin esitettäville varsinaisille tuloksille. Tulokset esitetään luvuissa 5-7. Koetin mukaan Augustinuksen teksteissä diakoneille piirtyy useita rooleja: Diakoni on sekä viestinviejä, evankelista että saarnaaja. Koetin kuvaus diakonin tehtävänkuvasta 
vastaa siten hyvin Collinsin märitttelemää Uuden testamentin diakonien gobetweeen -luonnetta.

Augustinuksen teksteissä diakonit tulevat esille monin tavoin tekstilajista riippuen. Systemaattista esitystä heidän toimenkuvastaan, esimerkiksi jumalanpalveluksen yhteydessä, ei kirkkoisä ole kirjoittanut. Sitä vastoin hän on esimerkiksi saarnannut monista pyhistä diakoneista. Hajanaisista lähteistä huolimatta Koet on pystynyt muodostamaan kattavia linjoja Augustinuksen diakoni-käsityksestä. Analyysi keskittyy pelkästään miesdiakoneihin, sillä kaikki lähdeteksteistä esille tulevat diakonit ovat miehiä. Kirjan viimeinen, johtopäätöksiä käsittelevä, luku on hyvin selkeä ja tiivistää teoksen olennaisen sisällön. Suosittelenkin aloittamaan lukemisen siitä.

Teos on perusteellinen, tiivis ja kattava. Erityisesti pidän selkeästä cursus honorum -kehityksen analyysista, jollaista olen aiemmin etsimällä etsinyt. Minun on kuitenkin vaikea arvioida, avautuuko kirjan punainen lanka yhtä selkeästi lukijalle, joka ei ole pohtinut samoja kysymyksiä useiden vuosien ajan. Ehkä kokonaisuus hahmottuu hänen mielessään hajanaisempana. Sen sijaan ihailen Koetin tapaa aloittaa luvut. Kauniisti kirjoitetut narratiivit vievät mielen kuin itsestään aiheen äärelle. Koet ei kirjoita tieteellistä tekstiä tylsästi.

Koet liittää taidokkaasti uuden diakonian tutkimuksen osaksi nykyistä Augustinus-tutkimusta. Brill's Studies in Catholic Theology -sarjassa julkaistu teos ei kuitenkaan ole merkittävä kontribuutio pelkästään akateemisesta vaan erityisesti roomalais-katolisen kirkon näkökulmasta katsottuna. Katolisten teologien keskuudessa uudelleentulkittu diakoni-käsite ei ole saanut yhtä kiinnostunutta vastaanottoa kuin protestanttisessa kontekstissa. Siten katolisen tutkijan (ja diakonin) oman kirkkonsa korkeasti arvostamaa kirkkoisää koskevaa tutkimusta ja uutta diakonian paradigmaa yhdistävä teos voi avata monen lukijan silmiä. Teoksella onkin varmasti annettavaa katolisessa kirkossa parhaillaan käytäville diakoniaan liittyville keskusteluille.

Eräs asia jäi askarruttamaan minua kirjaa lukiessani. Esipuheessaan Koet pitää diakoneja seurakunnan avustavina johtajina ("assistant leaders"). Juutuin tässä samaan vanhaan pähkinään kuin monesti aikaisemminkin. Minkä vuoksi diakonien rooli seurakunnan johtajan agentteina tekee automaattisesti heistä itsestäänkin johtajia? Jos sinä löydät kirjasta vastauksen tähän pieneen suureen kysymykseeni, vinkkaathan minulle. Kiitos jo etukäteen! 